\title{
ESTIMATION OF CARBON SEQUESTRATION IN MACADAMIA NUT IN KASKI DISTRICT, NEPAL
}

\author{
A. P. Timilsina ${ }^{1}$, A. Gaire ${ }^{1}$, G. Malla ${ }^{1}$, B. Paudel ${ }^{1}$, R. Rimal ${ }^{1}$ and H. Bhandari ${ }^{1}$
}

\begin{abstract}
Fruit tree plantation is well favored by the climatic and topographic conditions of Nepal. Widening its area coverage has a more significant potential option to reduce atmospheric carbon through sequestration in tree biomass as well as in carbon trading. However, databases on the quantityof carbon sequestrated by fruit trees in Nepal is lacking due to use of destructive sampling method but very demanding. The Pnondestructive method of carbon estimations like allometric method explores the advantages of saving time, research efforts and money. Therefore, this has been done to estimate the amount of carbon sequestrated by macadamia nut in Kaski district in Nepal. The result showed that macadamia nut fixes $3.35 \mathrm{CO}_{2}$ e t/ha/year. Moreover, the average carbon sequestration per plant per year was $100 \mathrm{~kg}$. The finding supports the view that the fruits trees could act as a significant sink for atmospheric carbon dioxide and need topromote its plantations fromecological point of view.
\end{abstract}

Keywords: Allometric, biomass, carbon sequestration, macadamia nut

\section{INTRODUCTION}

Nepal enjoys very diverse climate within very short span moving from south to northwards that has given tremendous opportunity to grow perennial fruits plants. Currently, fruits plants cover about 1,16,934 ha of cultivated land (AICC, 2018). Fruits including spices share about $7.04 \%$ of the total gross domestic products contributed by Agriculture sector in 2013/2014 (Pandey et al., 2017). Therefore, fruit crops in Nepal hold greater significance regarding both area coverage and country economy. Further, Nepal has the considerable amount of undulated land, especially in the hilly region, which is best suitable for the fruit plantation rather than cereals crops considering various forms of soil degradation including landslides and erosion.

Global warming, as a result of higher atmospheric green house gas concentration, is one of the most alarming issues of the present. One of the options for reducing the rise of green house gas concentration in the

1 Nepal Agricultural Research Council, Agricultural Environment Research Division, Khumaltar, Lalitpur, Nepal.

Corresponding author: Email: timilsinaamit87@gmail.com, Mobile number: +977 9855047733 
atmosphere and thus possible climate change, is to increase the amount of carbon removed by and stored in plants. Forests act as a vast reservoir as well as potential carbon sink to restore the atmospheric $\mathrm{CO}_{2}$ in the form of biomass as leaves, trunk, roots, etc. With increasing deforestation that contributes onequarter of the $\mathrm{CO}_{2}$ level worldwide (Oli and Shrestha, 2009), replacing the area with fruit trees will increase the carbon sequestration with nutritional as well as economic benefits. In the context of Nepal, few efforts have been made to estimate the amount of the carbon stored in a tree in different forms. The carbon could be estimated in various ways.

However, the non-destructive sampling methods using the allometric equations are widely used to save the time, money and other resources. An allometric equation is a model developed based on the real destructive sample to explore the sink and source relationships.

Macadamia (Macadamia spp) is an evergreen perennial fruit tree; one of the major nuts in Nepal getting attention by the Nepalese farmers in recent days (Barrueto et al., 2018a; Barrueto et al., 2017). The tree could be grown successfully up to 1700 meter above sea level (Barruetoet al., 2017) and its suitability in terms of area for the cultivation is being expected to increase in future (Barrueto et al., 2018b). Therefore, this study was conducted for assessing the amount of carbon sequestrated by macadamia nut in the mid-hills area, Malepatan, Kaski district in Nepal.

\section{METHODOLOGY}

\section{STUDY AREA}

\section{Geography and Climate}

The Horticultural Research Station, Malepatan lies in Pokhara Sub-metropolitan

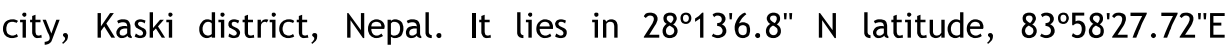
longitude and 848 meters above sea level. The average annual maximum and minimum temperature of the study location is $31.9^{\circ} \mathrm{C}$ and $6.9^{\circ} \mathrm{C}$, respectively. The station receives $4463.6 \mathrm{~mm}$ rainfall per annum (HRS, 2015). The soil texture is sandy loam. The sampled macadamia nut trees were planted at a spacing of $5 \times 5 \mathrm{~m}^{2}$ in 1.33-hectare land which were aged 24 . Therefore, there were 400 plants per hectare. The samples were collected on $28^{\text {th }}$ October 2015. 


\section{Calculation of Physical Parameters}

The plant height and weight are an important indicator for the tree weight or biomass and are very useful to estimate the plant overall biomass allometrically (Ravindranath and Ostwald, 2008). Girth at breast height (GBH) and plant height were measured for each sampled tree. Clinometers used to measure the plant height whereas GBH was measured at $1.3 \mathrm{~m}$ height of the plant. While using the clinometer, observer stood far enough from the plant to be measured so that the top of the plant is easily visible. Then, the angle of vision to the top of the pole from observer (clinometer reading in degree) was recorded. With the help of the height of the observer eye from the ground level (observer eye-height), the height of the plant was calculated using equation 1 . The method of measuring plant height is shown in Figure 1.

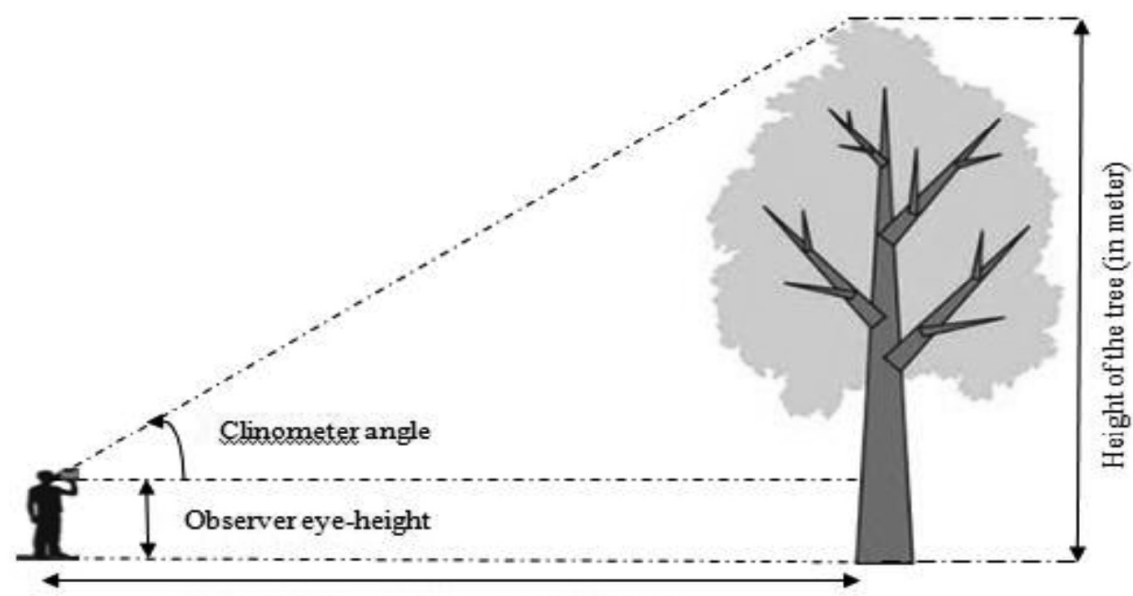

Distance between observer and the tree

Figure 1. Schematic diagram for measuring tree height

Tree height $=$ tan (clinometer reading in degree) $X$ distance between an observer and the tree +observer eye-height Equation 1

\section{Algometric Estimation of Tree Carbon Pool}

The above-ground biomass (AGB) and below-ground biomass (BGB) constitute the living biomass of the tree. The above-ground biomass takes in all the visible parts of the trees above the soil. The visible parts include bark, stem, branch, leaves, and seeds. The live roots with at least 2-millimeter diameter make the below-ground biomass. Both the biomass generally expressed in tonnes of biomass per hectare (Ravindranath and Ostwald, 2008; Chavan and Rasal, 2012). 


\section{Estimation of Above-Ground Biomass}

The above-ground biomass was calculated using the simple equation as

Dry weight of the tree as AGB (in $\mathrm{kg}$ ) $=\left[\mathrm{V} \mathrm{X} \mathrm{WD}\left(\mathrm{g} / \mathrm{cm}^{3}\right)\right] / 1000$......Equation2

Where,

$$
\begin{aligned}
& V=\text { Volume of the tree }\left(\mathrm{cm}^{3}\right) \\
& W D=\text { Wood density }\left(\mathrm{g} / \mathrm{cm}^{3}\right)
\end{aligned}
$$

The volume of the tree was calculated using the girth at breast height and plant height. The wood density value varies with plant type as well as species.

\section{Estimation of Below Ground Biomass}

As measurement of the root biomass is costly, non-feasible and time taking procedure, the below ground biomass is calculated using the allometric equation with the help of the dry weight of the tree as AGB (Equation 3). Dry weight of the root biomass as $B G B$ (in $\mathrm{kg}$ ) $=R X$ dry weight of the tree ( $\mathrm{kg})$. Equation3

Where,

$$
\mathrm{R}=\text { root to shoot ratio }
$$

The value of the root to shoot ratio is based on the literature. The mean value of the root to shoot ratio (0.26) is used as per Cairns et al. (1997).

\section{Estimation of Carbon Sequestration}

The carbon sequestrated was calculated as fifty percent of the total biomass or carbon-dioxide sequestrated (Murhpy et al., 2013).

\section{RESULTS AND DISCUSSION}

The total of 24 years old forty-five tree samples were classified into five different classes at an interval of $15 \mathrm{~cm}$ based on the girth at breast height. This classification was mainly done to understand the better picture of various aspects of the study. The estimation was done for the individual sampled tree and converted to hectare basis using total plant population per hectare. 
Table 1: Physical parameters, estimated biomass and $\mathrm{CO}_{2}-\mathrm{C}$ sequestrationof macadamia nut tree

\begin{tabular}{ccccccc}
\hline $\begin{array}{c}\text { Diameter at } \\
\text { breast } \\
\text { height class } \\
(\mathrm{cm})\end{array}$ & $\begin{array}{c}\text { Number of } \\
\text { samples }\end{array}$ & $\begin{array}{c}\text { Plant } \\
\text { height } \\
(\mathrm{m})\end{array}$ & $\begin{array}{c}\text { Above } \\
\text { ground } \\
\text { biomass } \\
(\mathrm{t} / \mathrm{ha})\end{array}$ & $\begin{array}{c}\text { Below } \\
\text { ground } \\
\text { biomass } \\
(\mathrm{t} / \mathrm{ha})\end{array}$ & $\begin{array}{c}\mathrm{CO}^{-}- \\
\text {sequestrated } \\
(\mathrm{t} / \mathrm{ha})\end{array}$ & $\begin{array}{c}\mathrm{C} \\
\text { sequestrated } \\
(\mathrm{t} / \mathrm{ha} / \text { year })\end{array}$ \\
\hline $20-35$ & 9 & 5.27 & 12.13 & 3.15 & 15.28 & 7.64 \\
$35-45$ & 6 & 5.62 & 25.06 & 6.52 & 31.58 & 15.79 \\
$45-60$ & 16 & 7.21 & 54.39 & 14.14 & 68.53 & 34.27 \\
$60-75$ & 9 & 7.84 & 95.84 & 24.92 & 120.76 & 60.38 \\
$75-90$ & 5 & 9.02 & 175.65 & 45.67 & 221.32 & 110.66 \\
\hline Average & - & $\mathbf{6 . 9 4}$ & $\mathbf{6 3 . 7 9}$ & $\mathbf{1 6 . 5 9}$ & $\mathbf{8 0 . 3 8}$ & 40.19 \\
\hline
\end{tabular}

\section{PLANT HEIGHT}

Out of forty-five samples, more than third (16) fall under $45-60 \mathrm{~cm}$ GBH class (Table 1). The plant height of macadamia nut ranged from 4.15 to $10.93 \mathrm{~m}$ with an average height of $6.94 \mathrm{~m}$. The plant height has increased with increase in the girth at breast height.

\section{THE ABOVE-GROUND BIOMASS}

The above ground biomass was calculated using Equation 2 with the wood density as $0.8 \mathrm{gm}^{-3}$ (Carsan et al., 2012). The $\mathrm{CO}_{2}$ sequestrated as the above ground biomass was ranged from 12 to $544 \mathrm{~kg} /$ tree. The average above ground biomass per tree was found $159 \mathrm{~kg}$ per tree. Moreover, the average AGB for the entire plants per hectare was found at $63.79 \mathrm{t}$. The AGB found higher with higher plant height and girth at breast height.

\section{THE BELOW-GROUND BIOMASS}

The average $\mathrm{CO}_{2}$ sequestrated as average below ground biomass per tree was $41 \mathrm{~kg}$ with a range from 3 to $141 \mathrm{t}$ per hectare. Further more, average below ground biomass per hectare was found $16.59 \mathrm{t}$ per hectare. The similar relationship exists with the plant height and girth at breast height as seen in the above-ground biomass.

\section{THE ESTIMATION OF TOTAL CARBON-DIOXIDE SEQUESTRATED}

The total carbon-dioxide sequestrated is the simple addition of the aboveground and below-ground biomass. The average carbon-dioxide sequestrated per tree was $201 \mathrm{~kg}$ with a range from 15 to $685 \mathrm{~kg}$ per tree. Similarly, the range for the one-hectare macadamia nut plantation was found 6.1 to 274.1 
tonnes with an average of 80.38 tonnes per hectare. Since the plantation was twenty-four years old, the average for the macadamia nut sequestration was found $3.35 \mathrm{CO}_{2} \mathrm{e} \mathrm{t} / \mathrm{ha} /$ year which is in coherence with the finding of Murhpy et

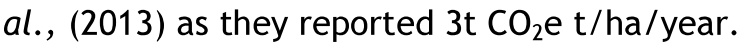

\section{CARBON SEQUESTRATED}

The range of carbon sequestration wasfrom 8 to $343 \mathrm{~kg}$ per tree with an average of $100 \mathrm{~kg}$ per tree. Similarly, the average carbon sequestrated per hectare was recorded as 40.19 tonnes per hectare with an average carbon sequestration range from 3.07 to 137.01 tonnes per hectare.

Nepal with the small economy and agriculture being one of the major bone of the livelihood, the local production of the fruits helps to secure economic as well as nutritional requirements of the country. In the context of the increasing the deforestation as well as a vulnerability on the landslide, fruit plantation helps to mitigate as well as to reduce the impact of the climate change. Though macadamia nut is a new fruit in case of Nepal, the nutritional properties as well climatic suitability makes it one of the potential crops in Nepal. In addition, its ability to fix the carbon dioxide is an advantage for carbon farming as the carbon sequestration level was equivalent to the country (Australia) with higher suitability of climate and major producer of the macadamia nut (Murphy et al., 2013). Furthermore, as the Climate Change Policy (2011) of the Nepal keeps emphasis on the low carbon emission development path, the encouragement to the farmers to grow the multipurpose tree like macadamia nut would play a significant role to contribute to the national policy.

\section{CONCLUSION}

Fruits plantation reserves a better option to exploit the geography and climatic conditions of Nepal. Besides, its ability to sink the atmospheric carbon dioxides makes it potential mitigator of climate change. The macadamia nut, having future perspective in Nepal, was found to sequestrate the $3.35 \mathrm{CO}_{2} \mathrm{e}$ t/ha/year with $100 \mathrm{~kg} / \mathrm{ha}$ average carbon sequestration per year per tree. This research output might be helpful to make the national databases on carbon footprint of the horticultural crops. However, further research on diverse soil, climate, management as well as varieties or species provides the better picture on carbon footprint of this fruit trees and other fruit and plantation trees on a national level. 
The Journal of Agriculture and Environment Volume: 20, June, 2019

\section{ACKNOWLEDGEMENT}

The author is highly obligated to Agricultural Environment Research Division under Nepal Agricultural Research Council helping through technical as well as other inputs and support to accomplish the research. The author like to extend his sincere thanks to all the technical as well as administrative support staff of Agricultural Environment Research Division, Khumaltar, Nepal.

\section{REFERENCES}

AICC. 2018. Krishi diary2075. Government of Nepal, Nepal: Agricultural Information and Communication Centre, Department of Agriculture. HariharBhawan, Lalitpur, Nepal.

Barrueto, A. K., Niraula, R., Merz, J., Pokharel, B. and Hammer, T., 2018b. Climatic suitability predictions for the cultivation of macadamia and walnuts in existing land-use zones and forest management regimes under climate change scenarios: addressing food security in the mid-hills of Nepal. Forests, Trees and Livelihoods, 27:2, 86-102, doi: 10.1080/14728028.2018.1438930.

Barrueto, A.K., Merz, J., Hodel, E. and Eckert, S., 2017. The suitability of Macadamia and Juglans for cultivation in Nepal: An assessment based on spatial probability modelling using climate scenarios and in situ data. Regional Environmental Change, 18(3), 859-871. doi:https://doi.org/10.1007/s10113-017-1225-2.

Barrueto, A.K., Merz, J., Kohler, T. and Hammer, T., 2018a. What Prompts Agricultural Innovation in Rural Nepal: A Study Using the Example of Macadamia and Walnut Trees as Novel Cash Crops. Agriculture, 8(2):1-16.

Cairns, M.A., Brown, S., Helmer, E.H. and Baumgardner G.A., 1997. Root biomass allocation in the world's upland forests. Oecologia, 111(1):1-11. doi: https://doi.org/10.1007/s004420050201.

Carsan, S., Orwa, C., Harwood, C., Kindt, R., Stroebel, A., Neufeldt, H., and Jamnadass, R., 2012.African Wood Density Database. World Agroforestry Centre, Nairobi.

Chavan, B. and Rasal, G., 2012. Total sequestered carbon stock of Mangiferaindica. Journal of Environment and Earth Science, 2(1): 37-48.

HRS.2015. Annual report 2071/72 (2014/15). Horticulture Research Station.Pokhara-5, Malepatan, Kaski, Nepal.

Murphy, T., Jones, G., Vanclay, J. and Glencross, K., 2013. Preliminary carbon sequestration modelling for the Australian macadamia industry. Agroforest Syst, 87: 689-698. doi: 10.1007/s10457-012-9589-2 
Oli, B. and Shrestha, K., 2009. Carbon Status in Forests of Nepal: An Overview. Journal of Forest and Livelihood, 8(1): 62-66. Retrieved from https: //www.nepjol.info/index.php/JFL/article/view/1885.

Pandey, G., Basnet, S., Pant, Bibek., Bhattarai, K., Gyawali, B. and Tiwari, A., 2017. An analysis of vegetables and fruits production scenario in Nepal.Asian Research Journal of Agriculture, 6(3):1-10. doi:10.9734/ARJA/2017/36442.

Ravindranath, N.H and Ostwald, M., 2008. Carbon inventory methods-Handbook for greenhouse gas inventory, carbon mitigation and round wood production projects. Advances in Global Change Research, Springer, Verlag, Berlin, 304. 